\title{
Science Fun: Theory of Light
}

* S Khoiriyah ${ }^{1}, \mathbf{A}$ K Sukma1
${ }^{1}$ Department of Physics, Faculty of Mathematics and Natural Science, Universitas Negeri Surabaya, Surabaya 60231, Indonesia

\begin{tabular}{|c|c|}
\hline Article Info & ABSTRACT \\
\hline $\begin{array}{l}\text { Article history: } \\
\text { Received March 23, } 2020 \\
\text { Revised April 9, 2020 } \\
\text { Accepted April 12, } 2020 \\
\text { Available Online April 13, } 2020\end{array}$ & $\begin{array}{l}\text { We as budding researchers, try to present science in the form of } \\
\text { comics. We present the theory of light by Christiaan Huygens and Sir } \\
\text { Isaac Newton in a short comic strip. }\end{array}$ \\
\hline $\begin{array}{l}\text { Keywords: } \\
\text { Theory of light } \\
\text { Huygens } \\
\text { Newton } \\
\text { Comic }\end{array}$ & \\
\hline (A) Check for updates open access Cc & https://doi.org/10.46627/sipose \\
\hline
\end{tabular}

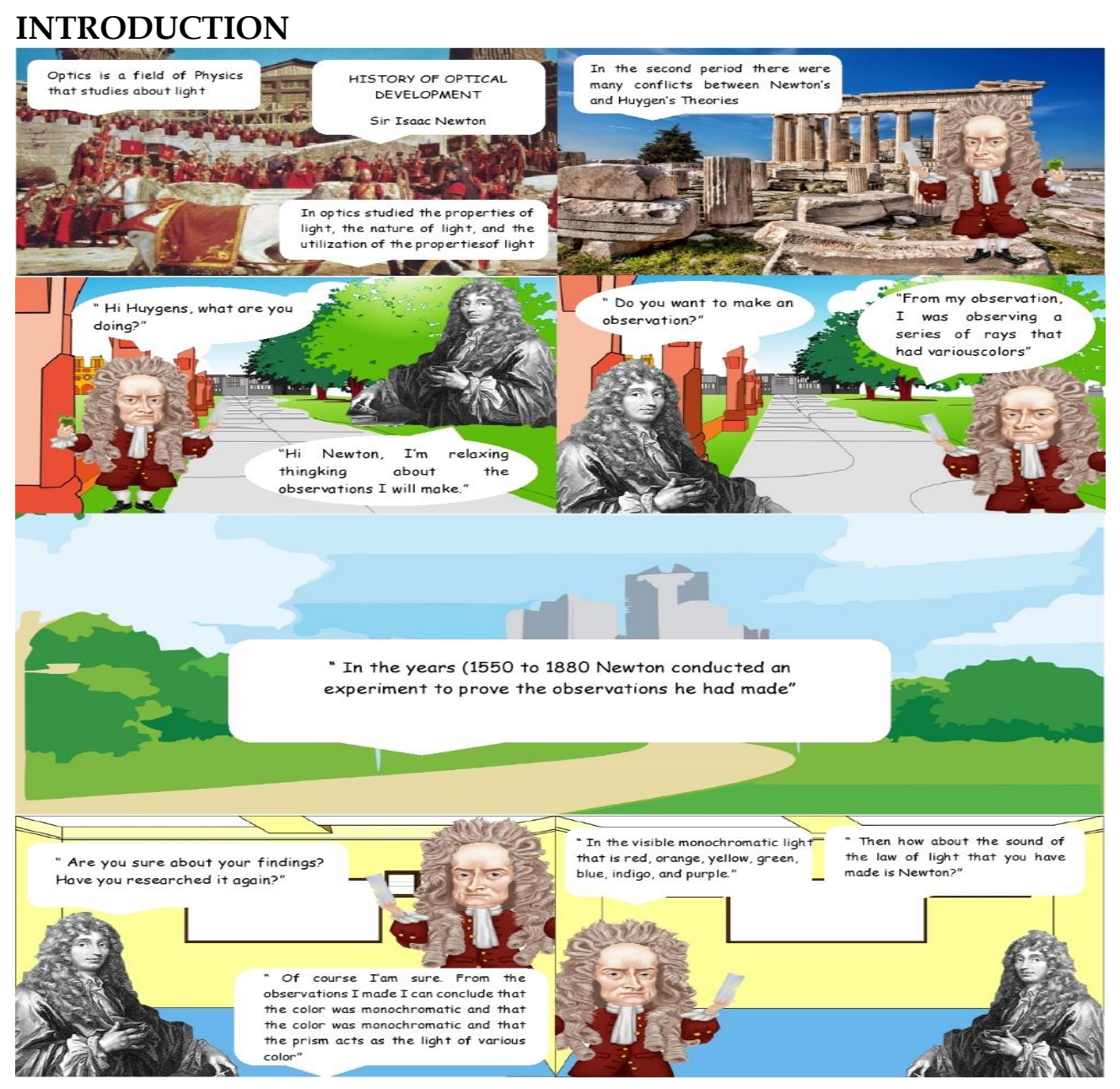




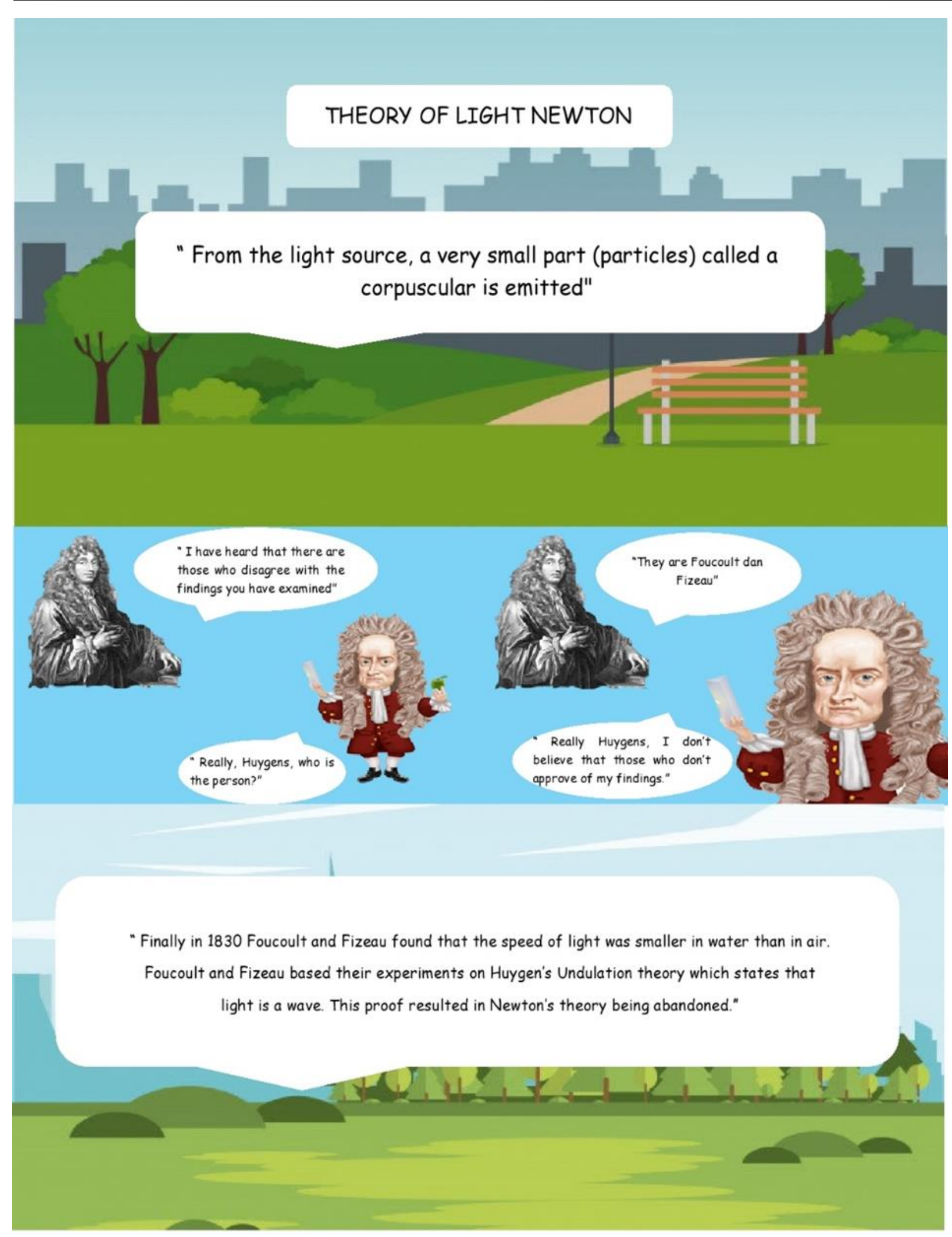




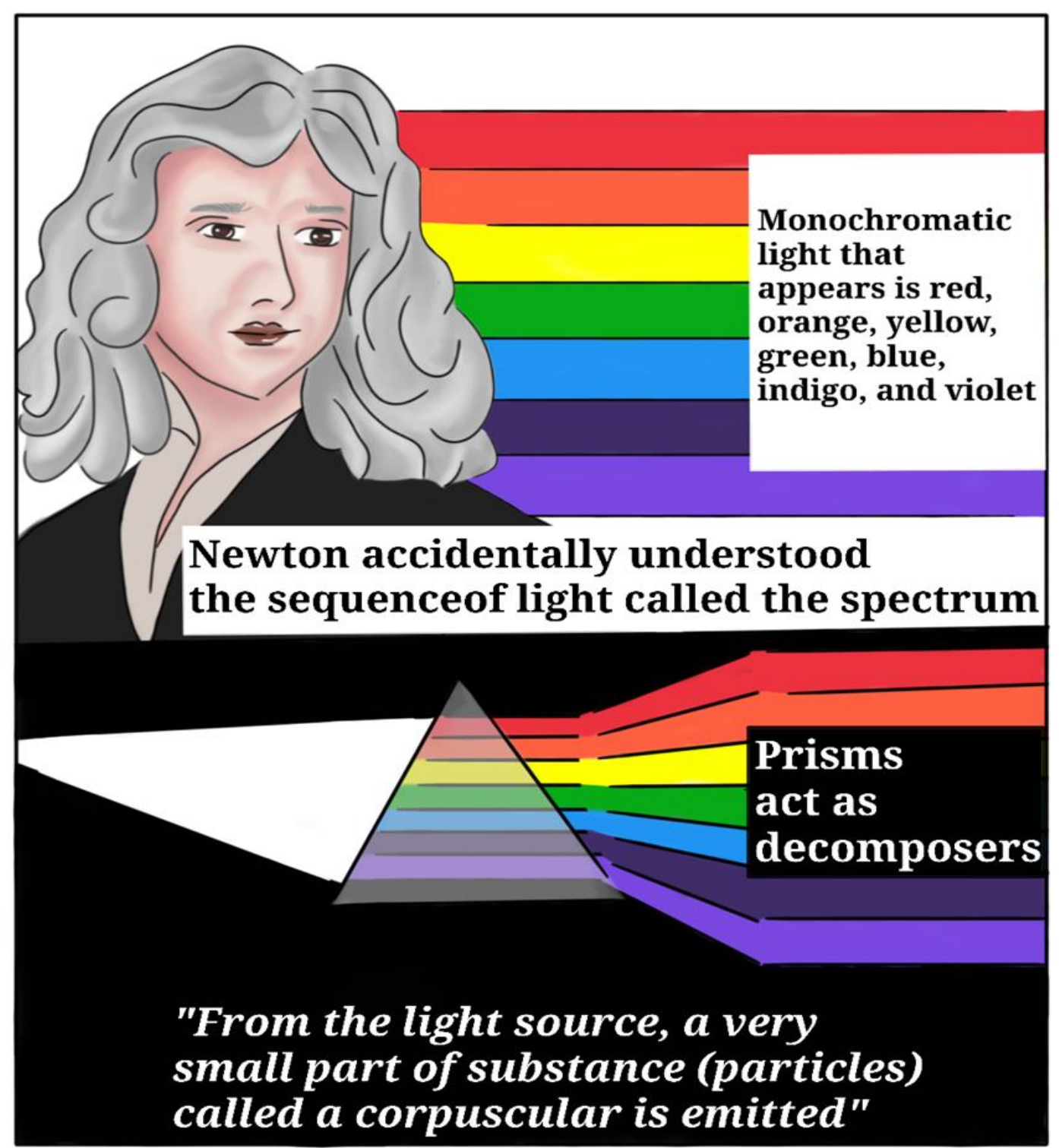

\section{REFERENCES}

Suprapto, N., \& Dwikoranto. (2019). Sejarah Fisika. Surabaya: JDS.

\section{Authors:}

* Saidatul Khoiriyah (Corresponding Author)

Department of Physics, Faculty of Mathematics and Natural Science,

Universitas Negeri Surabaya,

Jl. Ketintang, Surabaya 60231, Indonesia

Email: saidatulkhoiriyah05@gmail.com

\section{Adhelia Karunia Sukma}

Department of Physics, Faculty of Mathematics and Natural Science,

Universitas Negeri Surabaya,

Jl. Ketintang, Surabaya 60231, Indonesia

Email: Aksadhelia@gmail.com 